\title{
ANALISIS KEMAMPUAN GURU PENDIDIKAN AGAMA ISLAM DALAM PENYUSUNAN RENCANA PELAKSANAAN PEMBELAJARAN (RPP) KURIKULUM 2013
}

\author{
Erni Vidiarti*, Zulhaini**, Andrizal*** \\ Universitas Islam Kuantan Singingi, Riau, Indonesia \\ Email: *ErniVidiarti@gmail.com, **Zulhaini@gmail.com, ***Andrizal_01@gmail.com
}

\begin{abstract}
This research aims to analyze the ability of Islamic religious education teachers in the preparation of the plan of implementation of the learning (RPP) Curriculum 2013 in SD Negeri 016 Source Flat Singingi Subdistrict. This research includes research with qualitative, descriptive approach to research that is used to describe and analyze the phenomena, events, social activities, attitudes, beliefs, perceptions, and people individually and the group, with the techniques of data collection through the techniques of observation, interview and documentation. Results of the study showed that the ability of guru PAI in the preparation of RPP 2013 in elementary curriculum Land Resource 016 Flat Sub Singingi categorized "very good" with four stages of the observation by the author with the average scores $86.25 \%$ ketercapaian the ability of teachers, it is visible from the completeness of the RPP made by the teacher concerned.
\end{abstract}

Keywords: Ability of PAI Teachers; RPP; Curriculum 2013.

\begin{abstract}
Abstrak: Penelitian ini bertujuan untuk menganalisis kemampuan guru pendidikan agama Islam dalam penyusunan Rencana Pelaksanaan Pembelajaran (RPP) Kurikulum 2013 di SD Negeri 016 Sumber Datar Kecamatan Singingi. Penelitian ini menggunakan pendekatan deskriptif kualitatif yaitu penelitian yang digunakan untuk mendeskripsikan dan menganalisis fenomena, peristiwa, aktivitas sosial, sikap, kepercayaan, persepsi, dan orang secara individual dan kelompok, dengan teknik pengumpulan data melalui teknik observasi, wawancara dan dokumentasi. Hasil penelitian menunjukan bahwa kemampuan guru PAI dalam penyusunan RPP kurikulum 2013 di SD Negeri 016 Sumber Datar Kecamatan Singingi dikategorikan "sangat baik" dengan 4 tahapan observasi oleh penulis yaitu dengan rata-rata skor $86,25 \%$ ketercapaian kemampuan guru, ini terlihat dari kelengkapan RPP yang dibuat oleh guru yang bersangkutan.
\end{abstract}

Kata Kunci: Kemampuan Guru PAI; RPP; Kurikulum 2013.

\section{PENDAHULUAN}

Pendidikan merupakan investasi dalam pengembangan sumber daya manusia dan dipandang sebagai kebutuhan dasar bagi masyarakat yang ingin maju. Komponen-komponen sistem pendidikan yang mencakup sumber daya manusia dapat digolongkan menjadi dua yaitu: Tenaga Kependidikan Guru dan Non Guru. Menurut Undang-Undang Nomor 20 tahun 2003 tentang Sistem Pendidikan Nasional menyatakan, komponen-komponen sistem pendidikan yang bersifat sumber daya manusia dapat digolongkan menjadi tenaga pendidik dan pengelola satuan pendidikan (penilik, pengawas, peneliti dan pengembang pendidikan).

Tenaga guru yang mendapatkan perhatian lebih banyak di antara komponen-komponen sistem pendidikan. Besarnya perhatian terhadap guru antara lain dapat dilihat dari banyaknya kebijakan khusus seperti kenaikan tunjangan fungsional guru dan sertifikasi guru.

Proses pengembangan kinerja guru terbentuk dan terjadi dalam kegiatan belajar mengajar di tempat mereka bekerja, Selain itu kinerja guru dipengaruhi oleh hasil pembinaan dan supervisi kepala sekolah (Made Pidarta, 1992:3). Pada pelaksanaan Kurikulum 2013 menuntut kemampuan baru pada guru untuk dapat mengelola proses pembelajaran secara efektif dan efisien. Tingkat 
produktivitas sekolah dalam memberikan pelayanan-pelayanan secara efisien kepada pengguna (peserta didik, masyarakat) akan sangat tergantung pada kualitas gurunya yang terlibat langsung dalam proses pembelajaran dan keefektifan mereka dalam melaksanakan tanggung jawab individual dan kelompok.

Direktorat Pembinaan Pendidikan Dasar menyatakan "kualitas pendidikan sangat ditentukan oleh kemampuan sekolah dalam mengelola proses pembelajaran, dan lebih khusus lagi adalah proses pembelajaran yang terjadi di kelas, mempunyai andil dalam menentukan kualitas pendidikan konsekuensinya, adalah guru dituntut untukmelakukan perencanaan pembelajaran agar dapat menyampaikan materi pelajaran kepadasiswa secara sistematis dan tepat, sehingga tujuan pembelajaran yang diharapkan dapattercapai. Perencanaan pembelajaran sebagai alat pandu pelaksanaan pembelajaran hendaknyadisusun guru sebelum kegiatan pembelajaran dilaksanakan. Melalui kondisi ini, penyusunanperencanaan pembelajaran merupakan bagian tugas administrasi guru yang berdampaklangsung bagi kepentingan pembelajaran. Dengan demikian, semakin baik perencanaanpembelajaran yang dikembangkan, maka diyakini akan semakin baik pula proses pelaksanaanpembelajaran.

Sebelum melakukan suatu perencanaan pembelajaran, seorang guru harus memahami terlebih dahulu definisi dari perencanaan pembelajaran itu sendiri, karena biasanya apabila guru kurang memahami makna dan tujuan dari adanya perencanaan pembelajaran, maka yang akan timbul adalah suatu ke-malasan dalam proses pembuatan perencanaan pembelajaran tersebut. Terkadang para guru tersebut juga menganggap bahwa silabus dan RPP terlalu konseptual, tidak terlalu relevan dengan kenyataan dalam mengajar. Padahal kalau kita benar-benar memahami langkah-langkah penyusunan dan pengembangan dari RPP, maka hal tersebut tidak akan terjadi. Karena RPP dibuat berdasarkan kondisi dan karakteristik siswa. Sehingga melalui penyusunan perencanaan pembelajaran ini guru akan dapat merancang pembelajaran dengan baik sehingga mereka pun mendapatkan banyak kesempatan untuk belajar bagaimana mengajar dan mengajar bagaimana belajar.

Peraturan Pemerintah Nomor 19 Tahun 2005 tentang 8 Standar Nasional Pendidikan menyatakan standar proses merupakan salah satu SNP untuk satuan pendidikan dasar dan menengah yang mencakup: 1)Perencanaan proses pembelajaran, 2)Pelaksanaan proses pembelajaran, 3)Penilaian hasil pembelajaran, 4)dan pengawasan proses pembelajaran. Perencanaan pembelajaran meliputi Silabus dan Rencana Pelaksanaan Pembelajaran (RPP).

Perencanaan pembelajaran merupakan langkah yang sangat penting sebelum pelaksanaan pembelajaran.Silabus dan RPP dikembangkan oleh guru pada satuan pendidikan. Guru pada satuan pendidikan berkewajiban menyusun Silabus dan RPP secara lengkap dan sistematis agar pembelajaran berlangsung secara interaktif, inspiratif, menyenangkan, menantang, memotivasi peserta didik untuk berpartisipasi aktif, serta memberikan ruang yang cukup bagi prakarsa, kreativitas, dan kemandirian sesuai dengan bakat, minat dan perkembangan fisik serta psikologis peserta didik.

Berdasarkan observasi awal yang dilakukan penulis di SD Negeri 016 Sumber Datar pada hari Senin, tanggal 21 Maret 2016, masalah yang terjadi dilapangan masih ditemukan adanya guru yang tidak bisa memperlihatkan RPP yang dibuat dengan berbagai alasan dan bagi guru yang sudah membuat RPP masih ditemukan adanya guru yang belum melengkapi komponen tujuan pembelajaran dan penilaian (soal, skor dan kunci jawaban), serta langkah-langkah kegiatan pembelajarannya masih dangkal.Soal, skor, dan kunci jawaban merupakan satu kesatuan yang tidak dapat dipisahkan.Pada komponen penilaian (Penskoran dan kunci jawaban) sebagian besar guru tidak lengkap membuatnya.

Di SD Negeri 016 Sumber Datar Singingi adalah sebuah sekolah Negeri yang memiliki 2 orang guru Pendidikan Agama Islam, yang kemudian dilanjutkan observasi oleh penulis disekolah tersebut.Hal senada juga disampaikan oleh bapak Priyanta, S.pd selaku kepala sekolah.Beliau menjelaskan bahwa masih ada beberapa masalah yang sering dihadapi oleh guru PAI dalam menyusun RPP, terutama pada komponen penilaian yang dianggap terlalu rumit.

Dari adanya gejala tersebut sangat diperlukan suatu analisis mengenai penyusunan RPP yang dilakukan oleh guru untuk mengetahui kemampuan guru dalam menyusun, memahami dan memeroses kegiatan pembelajaran yang tertuang dalam RPP yang merupakan hal terpenting 
sebelum melaksanakan proses pembelajaran. (Suharsimi Ari Kunto, 2010 : 57) Dari gejala dan kejadian tersebut penulis tertarik untuk meneliti bagaimana sebenarnya Kemampuan Guru PAI didalam menjalankan tugasnya sebagai tenaga pendidik khususnya dalam penyusunan RPP Kurikulum 2013.

\section{HASIL DAN PEMBAHASAN}

\section{Rencana Pelaksanaan Pembelajaran (RPP)}

Rencana pelaksanaan pembelajaran atau yang dikenal dengan istilah RPP merupakan suatu bentuk perencanaan pembelajaran yang akan dilaksanakan oleh pendidik dalam kegiatan pembelajaran. Dalam hal ini, seorang pendidik telah memperhatikan secara cermat, baik materi, penilaian, alokasi waktu, sumber belajar, maupun metode pembelajaran yang akan digunakan sehingga secara detail kegiatan pembelajaran sudah tersusun secara rapi dalam perencanaan pelaksanaan pembelajaran (M. Fadillah, 2014: 143-144).

Menurut Permendikbud No. 65 tahun 2013 tentang Standar Proses Pendidikan Dasar dan Menengah disebutkan bahwa Rencana Pelaksanaan Pembelajaran (RPP) adalah rencana kegiatan pembelajaran tatap muka untuk satu pertemuan atau lebih. RPP dikembangkan dari silabus untuk mengarahkan kegiatan pembelajaran peserta didik dalam upaya mencapai Kompetensi Dasar (KD).Rencana Pelaksanaan Pembelajaran (RPP)merupakan suatu rencana yang menggambarkan prosedur dan manajemen pembelajaran untuk mencapai satu atau lebih kompetensi dasar yang ditetapkan dalam standar isi dan jabarkan dalam silabus (Mulyasa, 2007:212).

Pendapat lain menyebutkan bahwa Rencana Pelaksanaan Pembelajaran merupakan skenario pembelajaran yang menjadi pegangan bagi guru untuk menyiapkan, menyelenggarakan dan mengevaluasi hasil kegiatan belajardan pembelajaran. Maksud Rencana Pelaksanaan Pembelajaran (RPP) dalam kurikulum 2013, yaitu penyusunan rencana pelaksanaan pembelajaran untuk setiap muatan pembelajaran (Bariyah, Lailatul, 2014: 7).

RPP pada hakekatnya merupakan perencanaan jangka pendek untuk memperkirakan atau memproyeksikan apa yang akan dilakukan dalam pembelajaran. Dengan demikian, RPP merupakan upaya untuk memperkirakan tindakan yang akan dilakukan dalam kegiatan pembelajaran. RPP perlu dikembangkan untuk mengkoordinasikan komponen pembelajaran, yakni: kompetensi dasar, materi standar, indicator hasil belajar, dan penilaian. Oleh karena itu, setiap pendidik pada satuan pendidikan berkewajiban menyusun RPP secara lengkap dan sistematis agar pembelajaran berlangsung secara interaktif, inspiratif, menyenangkan, menantang, efisien, memotivasi peserta didik untuk berpartisipasi aktif serta memberikan ruang yang cukup bagi prakarsa, kreatifitas, dan kemandirian sesuai dengan bakat, minat, dan perkembangan fisik serta psikologis peserta didik (Yuliharti, 2014: 14). Jadi dapat disimpulkan bahwasanya RPP mempunyai peranan pentingdalam proses belajar mengajar. Tanpa RPP guru akan merasa kesulitan dantidak sistematis ketika mengajar.

\section{Fungsi Rencana Pelaksanaan Pembelajaran (RPP)}

Sebagai seorang pendidik yang profesional guru yang baik akan berusaha sedapat mungkin agar pengajarannya berhasil. Salah satu factor yang bisa membawa keberhasilan itu, ialah guru senantiasa menyusun RPP sebelumnya. Sedikitnya terdapat 2 fungsi RPP dalam kurikulum 2013.Kedua fungsi tersebut adalah Fungsi Perencanaan dan Fungsi Pelaksanaan.

1. Fungsi Perencanaan

Fungsi perencanaan RPP adalah bahwa rencana pelaksanaan pembelajaran hendaknya dapat mendorong guru lebih siap melakukan kegiatan pembelajaran dengan perencanaan yang matang. Oleh karena itu, setiap akan melakukan pembelajaran guru wajib memiliki persiapan, baik persiapan tertulis maupun tidak tertulis. Komponen-komponen yang harus dipahami guru dalam pengembangan kurikulum 2013 antara lain: kompetensi dasar, materi standar, hasil belajar, indikator hasil belajar, penilaian, dan prosedur pembelajaran. (Mukhtar. 2013: 65)

2. Fungsi Pelaksanaan

Dalam pengembangan kurikulum 2013, rencana pelaksanaan pembelajaran harus disusun secara sistematik dan sistematis, utuh dan menyeluruh, dengan beberapa kemungkinan 
penyesuaian dalam situasi pembelajaran yang aktual. Dengan demikian, rencana pelaksanaan pembelajaran berfungsi untuk mengefektifkan proses pembelajaran sesuai dengan apa yang direncanakan. (Mizan, A., \& Badrun, K. 2014: 1 (2)) Dalam hal ini, materi standar yang dikembangkan dan dijadikan bahan kajian oleh peserta didik harus disesuaikan dengan kebutuhan dan kemampuannya, mengandung nilai fungsional, praktis, serta disesuaikan dengan kondisi dan kebutuhan lingkungan, sekolah, dan daerah. Oleh karena itu, kegiatan pembelajaran harus terorganisasi melalui serangkaian kegiatan tertentu, dengan strategi yang tepat dan mumpuni.

Sedangkan menurut Abdul Majid perencanaan pengajaran mempunyai fungsi penting dalam memandu guru untuk melaksanakan tugas sebagai pendidik dalam melayani kebutuhan siswanya. Ada beberapa manfaat perencanaan pengajaran dalam proses belajar mengajar, yaitu: (Abdul Majid, 2005: 22)

1. Sebagai petunjuk arah kegiatan dalam mencapai tujuan

2. Sebagai pola dasar dalam mengatur tugas dan wewenang bagi setiap unsur yang terlibat dalam kegiatan

3. Sebagai pedoman kerja bagi setiap unsur, baik unsur guru maupun unsur murid

4. Sebagai alat ukur efektif tidaknya suatu pekerjaan, sehingga setiap saat diketahui ketepatan dan kelambatan kerja

5. Untuk bahan penyusunan data agar terjadi keseimbangan kerja

6. Untuk menghemat waktu, tenaga, alat-alat dan biaya

Dapat disimpulkan bahwa fungsi perencanaan pengajaran bagi seorang guru adalah untuk mengefektifkan proses pembelajaran sesuai dengan apa yang direncanakan dengan perencanaan yang matang. Oleh karena itu, setiap akan melakukan pembelajaran guru wajib memiliki persiapan, baik persiapan tertulis maupun tidak tertulis.

\section{Langkah-langkah Penyusunan RPP}

Untuk dapat menyusun RPP yang baik dan benar, selainmemperhatikan prinsip pengembangan dan penyusunan tersebut, para gurujuga harus mengikuti langkah-langkah dalam menyusun RPP, khususnya pada Kurikulum 2013. Menurut Permendikbud No. 81 tahun 2013 adabeberapa langkah yang harus diikuti dalam penyusunan RPP, antara lain sebagai berikut:

1. Guru mencantumkan identitas, yang terdiri atas: nama sekolah, mata pelajaran / tema, atau subtema, kelas, semester, alokasi waktu yang ditentukan sesuai dengan keperluan untuk pencapaian KD dan beban belajar dengan mempertimbangkan jumlah jam pelajaran yang tersedia dalam silabus dan KD yang harus dicapai.

2. Menentukan Kompetensi Dasar (KD), dan indikator pencapaian kompetensi yang dikutip dari silabus.

3. Merumuskan tujuan pembelajaran berdasarkan kompetensi dasar dengan menggunakan kata kata operasional.

4. Mencantumkan materi ajar yang ditulis dalam bentuk uraian sesuai dengan rumusan indikator pencapaian kompetensi.

5. Memilih metode pembelajaran yang disesuaikan dengan situasi dan kondisi peserta didik serta karakteristik dari setiap kompetensi yang hendak dicapai yang tergambar jelas pada indikator pencapaian kompetensi.

6. Langkah pembelajaran ini memuat: kegiatan pendahuluan, kegiatan inti dan kegiatan penutup.

7. Mencantumkan sumber dan media belajar yang digunakan

8. Pemilihan sumber belajar mengacu pada rumusan yang ada pada silabus yang dikembangkan. Sumber belajar mencakup sumber rujukan, lingkungan, media cetak dan elektronik, narasumber, alat dan bahan. Sumber belajar dituliskan secara lebih operasional dan bisa langsung dikatakan bahan ajar apa yang digunakan. Misalnya sumber belajar dalam silabus dituliskan buku referensi, dalam RPP harus dicantumkan bahan ajar yang sebenarnya.

9. Menentukan penilaian yang meliputi penilaian proses dan hasil belajar. Yang terdiri dari tehnik, bentuk, instrument penilaian (tes dan non tes), kunci jawaban dan pedoman penskoran serta tugas. (Antonius. 2016: 54). 


\section{Faktor yang Mempengaruhi Kemampuan Guru}

Guru merupakan salah satu bentuk jasa profesional yang dibutuhkan dalam bidang pendidikan. Oleh karena itu, standar guru profesional merupakan sebuah kebutuhan mendasar yang harus dimiliki seperti yang tercantum didalam Peraturan Pemerintah Nomor 19 tahun 2005 tentang standar nasional yang terdiri atas 8 Standar Nasional Pendidikan, dan salah satu dari standar tersebut mengenai standar pendidik dan tenaga kependidikan yang menjelaskan bahwa guru profesional harus memiliki kualifikasi akademik, kompetensi sebagai agen pembelajaran, sehat jasmani dan rohani, serta memiliki kemampuan untuk mewujudkan tujuan Pendidikan Nasional. Sedangkan faktor yang mempengaruhi kemampuan guru antara lain (Jingga GM. 2013: 76):

1. Kepribadian yang menyangkut tingkah laku, wibawa, karakter yang akan berpengaruh terhadap proses interaksi.

2. Penguasaan bahan pelajaran

3. Penguasaan kelas

4. Cara guru berkomunikasi dengan peserta didik

5. Cara menciptakan suasana kelas yang kondusif

6. Memperhatikan prinsip individualitas

7. Standar kelulusan

Dengan demikian guru merupakan faktor penentu tingkat tinggi rendahnya kualitas hasil pendidikan. Sekalipun demikian, posisi strategis guru untuk meningkatkan mutu hasil pendidikan juga sangat dipengaruhi oleh kemampuan professional, kesejahteraan dan lain-lain. Untuk itu, guru dituntut untuk memiliki kemampuan yang tinggi, senantiasa menguasai materi yang akan diajarkan, dan selalu mengembangkan serta meningkatkan kemampuan dalam hal ilmu yang dimilikinya (Murip Yahya, 2013: 23)

\section{Hasil Penelitian}

Observasi dilakukan oleh kepada guru Pendidikan Agama Islam bagaimana kemampuannya sebagai tenaga pendidik dalam menyusun RPP kurikulum 2013 di SD Negeri 016 Sumber Datar Singingi yaitu:

Tabel 1. Hasil Observasi 1 terhadap Kemampuan Guru PAI dalam Penyusunan RPP Kurikulum 2013 di SDNegeri 016 Sumber Datar Singingi

\begin{tabular}{|c||l||c|c||}
\hline \multicolumn{1}{|c||}{ NO } & \multicolumn{1}{|c||}{ Hal Yang Diamati } & \multicolumn{2}{c||}{ Keterangan } \\
\hline 1 & Guru membuat RPP kurikulum 2013 & $\checkmark$ & Tidak \\
\hline 2 & $\begin{array}{l}\text { Guru mencantumkan identitas, nama sekolah, mata pelajaran/tema } \\
\text { subtema, kelas, semester, alokasi waktu }\end{array}$ & $\checkmark$ & \\
\hline 3 & $\begin{array}{l}\text { Menentukan Kompetensi Dasar, dan indikator pencapaian kompetensi } \\
\text { yang dikutip dari silabus }\end{array}$ & $\checkmark$ & \\
\hline 4 & $\begin{array}{l}\text { Kesesuaian perumusan pencapaian tujuan pembelajaran dengan } \\
\text { kompetensi inti }\end{array}$ & $\checkmark$ & \\
\hline 5 & Kejelasan materi pembelajaran & $\checkmark$ & \\
\hline 6 & $\begin{array}{l}\text { Kesesuaian metode dengan tujuan, materi, dan karakteristik peserta } \\
\text { didik }\end{array}$ & $\checkmark$ & \\
\hline 7 & $\begin{array}{l}\text { Kejelasan skenario pembelajaran (langkah - langkah kegiatan } \\
\text { pembelajaran : pendahuluan, inti, penutup). }\end{array}$ & & $\checkmark$ \\
\hline \hline 8 & $\begin{array}{l}\text { Kerincian dan kejelasan skenario pembelajaran pada tahap kegiatan } \\
\text { mengamati }\end{array}$ & $\checkmark$ & \\
\hline 9 & Kerincian dan kejelasan skenario pembelajaran pada tahap menanya & $\checkmark$ & \\
\hline 10 & $\begin{array}{l}\text { Kerincian dan kejelasan } \\
\text { skenario pembelajaran pada tahap kegiatan eksplorasi }\end{array}$ & $\checkmark$ & \\
\hline 11 & $\begin{array}{l}\text { Kerincian dan kejelasan skenario pembelajaran pada tahap kegiatan } \\
\text { asosiasi }\end{array}$ & & $\checkmark$ \\
\hline
\end{tabular}




\begin{tabular}{|c|l||c|c||}
\hline 12 & $\begin{array}{l}\text { Kerincian dan kejelasan skenario pembelajaran pada tahap kegiatan } \\
\text { komunikasi }\end{array}$ & $\checkmark$ & \\
\hline \hline 13 & Kesesuain teknik penilaian dengan kompetensi yang akan dicapai & $\checkmark$ & \\
\hline \hline 14 & Kelengkapan perangkat penilaian (soal, kunci, rubric penilaian) & $\checkmark$ & \\
\hline \hline 15 & Keterpaduan dan kesinkronan antar komponen dalam RPP & $\checkmark$ & \\
\hline \hline Jumlah $\underline{13} \times 100 \%$ & $\mathbf{1 3}$ & $\mathbf{2}$ \\
\hline \hline \multicolumn{2}{|l||}{ Skor $\quad 86 \%$} & $\mathbf{8 6 \%}$ & $\mathbf{1 4 \%}$ \\
\hline
\end{tabular}

Ketercapaian kemampuan guru : $86 \%$

Keterangan :

Skor $86-100 \%$ : Baik sekali

Skor $71-85 \%$ : Baik

Skor $55-70 \% \quad$ : Cukup

Berdasarkan hasil observasi 1 diperoleh data bahwa kemampuan guru PAI dalam penyusunan RPP kurikulum 2013 di SDN 016 Sumber Datar dari 15 item indikator bahwa sebanyak 13 item (86\%) sudah dilaksanakan dengan baik sekali, dan hanya 2 item (14\%) yang belum dilaksanakan dengan demikian penyusunan RPP kurikulum 2013 sudah dilakukan dengan baik sekali dengan ketercapaian kemampuan guru 86\%.

Table 2. Hasil Observasi II terhadap Kemampuan Guru PAI dalam Penyusunan RPP Kurikulum 2013 di SDNegeri 016 Sumber Datar Singingi

\begin{tabular}{|c|c|c|c|}
\hline \multirow{2}{*}{ NO } & \multirow{2}{*}{ Hal Yang Diamati } & \multicolumn{2}{|c|}{ Keterangan } \\
\hline & & Ya & Tidak \\
\hline 1 & Guru membuat RPP kurikulum 2013 & $\checkmark$ & \\
\hline 2 & $\begin{array}{l}\text { Guru mencantumkan identitas, nama sekolah, mata pelajaran/tema } \\
\text { subtema, kelas, semester, alokasi waktu }\end{array}$ & $\checkmark$ & \\
\hline 3 & $\begin{array}{l}\text { Menentukan Kompetensi Dasar, dan indikator pencapaian kompetensi } \\
\text { yang dikutip dari silabus }\end{array}$ & $\checkmark$ & \\
\hline 4 & $\begin{array}{l}\text { Kesesuaian perumusan pencapaian tujuan pembelajaran dengan } \\
\text { kompetensi inti }\end{array}$ & $\checkmark$ & \\
\hline 5 & Kejelasan materi pembelajaran & $\checkmark$ & \\
\hline 6 & $\begin{array}{l}\text { Kesesuaian metode dengan tujuan, materi, dan karakteristik peserta } \\
\text { didik }\end{array}$ & $\checkmark$ & \\
\hline 7 & $\begin{array}{l}\text { Kejelasan skenario pembelajaran (langkah - langkah kegiatan } \\
\text { pembelajaran : pendahuluan, inti, penutup) }\end{array}$ & & $\checkmark$ \\
\hline 8 & $\begin{array}{l}\text { Kerincian dan kejelasan skenario pembelajaran pada tahap kegiatan } \\
\text { mengamati }\end{array}$ & & $\checkmark$ \\
\hline 9 & Kerincian dan kejelasan skenario pembelajaran pada tahap menanya & $\checkmark$ & \\
\hline 10 & $\begin{array}{l}\text { Kerincian dan kejelasan } \\
\text { skenario pembelajaran pada tahap kegiatan eksplorasi }\end{array}$ & $\checkmark$ & \\
\hline 11 & $\begin{array}{l}\text { Kerincian dan kejelasan skenario pembelajaran pada tahap kegiatan } \\
\text { asosiasi }\end{array}$ & & $\checkmark$ \\
\hline 12 & $\begin{array}{l}\text { Kerincian dan kejelasan skenario pembelajaran pada tahap kegiatan } \\
\text { komunikasi }\end{array}$ & $\checkmark$ & \\
\hline 13 & Kesesuain teknik penilaian dengan kompetensi yang akan dicapai & $\checkmark$ & \\
\hline 14 & Kelengkapan perangkat penilaian (soal, kunci, rubric penilaian) & $\sqrt{ } \checkmark$ & \\
\hline 15 & Keterpaduan dan kesinkronan antar komponen dalam RPP & $\checkmark$ & \\
\hline & $\begin{array}{lcc}\text { Jumlah } & 12 \times 100 \% \\
& 15 & \\
\end{array}$ & 12 & 3 \\
\hline & Skor & $80 \%$ & $20 \%$ \\
\hline
\end{tabular}


Ketercapaian kemampuan guru: $80 \%$

Keterangan:

Skor $86-100 \%$ : Baik sekali

Skor $71-85 \% \quad$ : Baik

Skor $55-70 \%$ : Cukup

Berdasarkan hasil observasi II diperoleh data bahwa kemampuan guru PAI dalam penyusunan RPP kurikulum 2013 di SDN 016 Sumber Datar dari 15 item indikator bahwa sebanyak 12 item (80\%) sudah dilaksanakan dengan baik dan 3 item (20\%) yang belum dilaksanakan, dengan demikian penyusunan RPP kurikulum 2013 sudah dilakukan dengan baik dengan ketercapaian kemampuan guru $80 \%$.

Table 3. Hasil Observasi III terhadap Kemampuan Guru PAI dalam Penyusunan RPP Kurikulum 2013 di SD Negeri 016 Sumber Datar Singingi

\begin{tabular}{|c|c|c|c|}
\hline \multirow{2}{*}{ NO } & \multirow{2}{*}{ Hal Yang Diamati } & \multicolumn{2}{|c|}{ Keterangan } \\
\hline & & Ya & Tidak \\
\hline 1 & Guru membuat RPP kurikulum 2013 & $\checkmark$ & \\
\hline 2 & $\begin{array}{l}\text { Guru mencantumkan identitas, nama sekolah, mata pelajaran/tema } \\
\text { subtema, kelas, semester, alokasi waktu }\end{array}$ & $\checkmark$ & \\
\hline 3 & $\begin{array}{l}\text { Menentukan Kompetensi Dasar dan indikator pencapaian kompetensi } \\
\text { yang dikutip dari silabus }\end{array}$ & $\checkmark$ & \\
\hline 4 & $\begin{array}{l}\text { Kesesuaian perumusan pencapaian tujuan pembelajaran dengan } \\
\text { kompetensi inti }\end{array}$ & $\checkmark$ & \\
\hline 5 & Kejelasan materi pembelajaran & $\checkmark$ & \\
\hline 6 & $\begin{array}{l}\text { Kesesuaian metode dengan tujuan, materi, dan karakteristik peserta didik } \\
\end{array}$ & 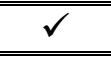 & \\
\hline 7 & $\begin{array}{l}\text { Kejelasan skenario pembelajaran (langkah - langkah kegiatan } \\
\text { pembelajaran: pendahuluan, inti, penutup) }\end{array}$ & $\checkmark$ & \\
\hline 8 & $\begin{array}{l}\text { Kerincian dan kejelasan skenario pembelajaran pada tahap kegiatan } \\
\text { mengamati }\end{array}$ & & $\checkmark$ \\
\hline 9 & Kerincian dan kejelasan skenario pembelajaran pada tahap menanya & $\checkmark$ & \\
\hline 10 & $\begin{array}{l}\text { Kerincian dan kejelasan } \\
\text { skenario pembelajaran pada tahap kegiatan eksplorasi }\end{array}$ & $\checkmark$ & \\
\hline 11 & $\begin{array}{l}\text { Kerincian dan kejelasan skenario pembelajaran pada tahap kegiatan } \\
\text { asosiasi }\end{array}$ & & $\checkmark$ \\
\hline 12 & $\begin{array}{l}\text { Kerincian dan kejelasan skenario pembelajaran pada tahap kegiatan } \\
\text { komunikasi }\end{array}$ & $\checkmark$ & \\
\hline 13 & Kesesuain teknik penilaian dengan kompetensi yang akan dicapai & $\checkmark$ & \\
\hline 14 & Kelengkapan perangkat penilaian (soal, kunci, rubric penilaian ) & $\bar{\checkmark}$ & \\
\hline 15 & Keterpaduan dan kesinkronan antar komponen dalam RPP & $\checkmark$ & \\
\hline \multicolumn{2}{|r|}{ Jumlah $\quad \underline{13} \times 100 \%$} & 13 & 2 \\
\hline \multicolumn{2}{|c|}{ Skor } & $86 \%$ & $14 \%$ \\
\hline
\end{tabular}

Ketercapaian kemampuan guru: $86 \%$

Keterangan:

Skor $86-100 \%$ : Baik sekali

Skor $71-85 \% \quad$ : Baik

Skor $55-70 \% \quad$ : Cukup

Berdasarkan hasil observasi III diperoleh data bahwa kemampuan guru PAI dalam penyusunan RPP kurikulum 2013 di SDN 016 Sumber Datar dari 15 item indikator bahwa sebanyak 13 item (86\%) sudah dilaksanakan dengan baik sekali dan 2 item (14\%) yang belum dilaksanakan, dengan demikian penyusunan RPP kurikulum 2013 sudah dilakukan dengan baik sekali dengan ketercapaian kemampuan guru 86\%. 
Tabel 4. Hasil Observasi IV terhadap Kemampuan Guru PAI dalam Penyusunan RPP Kurikulum 2013 di SDNegeri 016 Sumber Datar Singingi

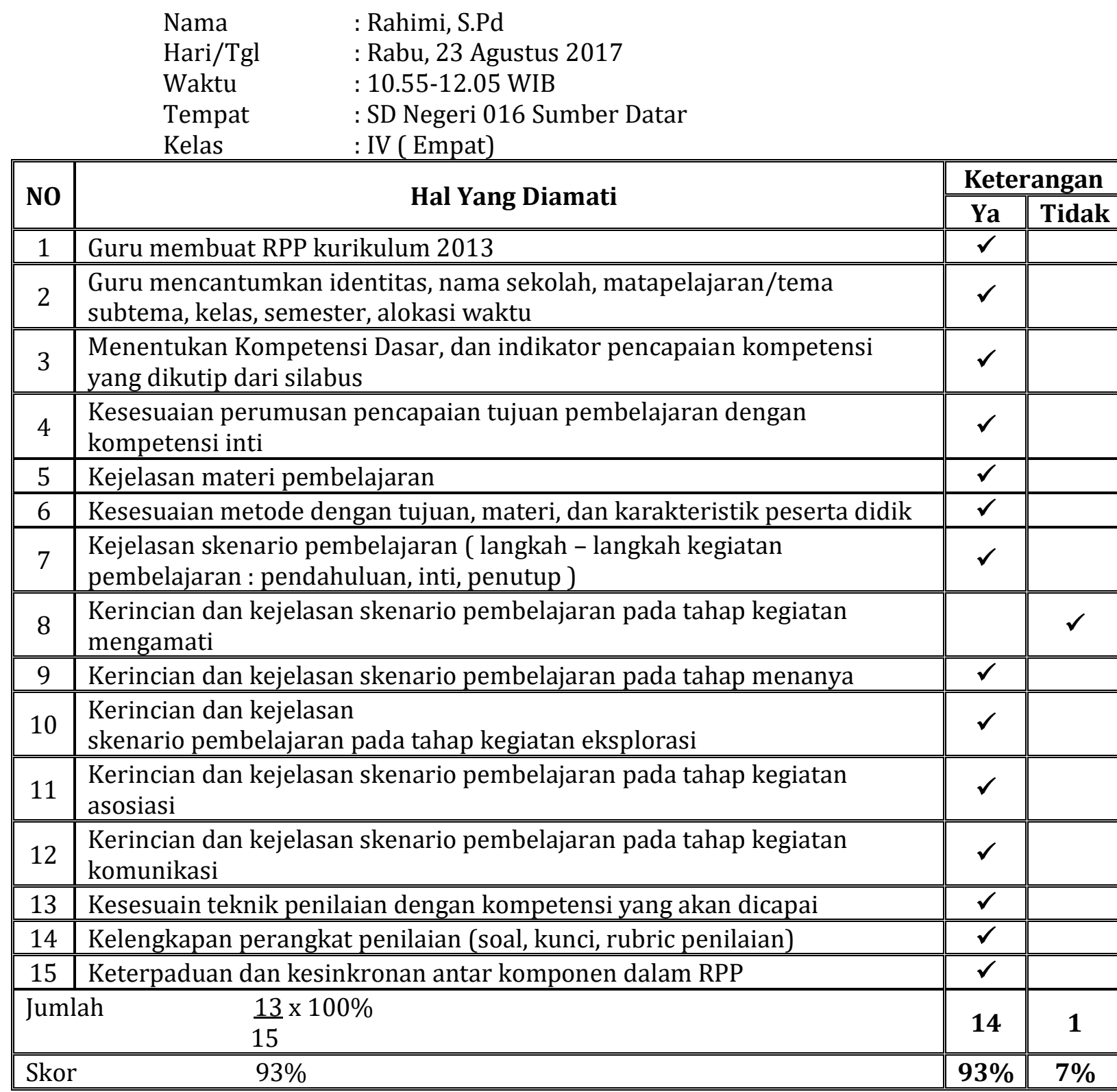

Ketercapaian kemampuan guru: 93\%

Keterangan:

Skor $86-100 \%$ : Baik sekali

Skor $71-85 \%$ : Baik

Skor $55-70 \%$ : Cukup

Berdasarkan hasil observasi IV diperoleh data bahwa kemampuan guru PAI dalam penyusunan RPP kurikulum 2013 di SDN 016 Sumber Datar dari 15 item indikator bahwa sebanyak 14 item (93\%) sudah dilaksanakan dengan baik sekali dan hanya 1 item (7\%) yang belum dilaksanakan, dengan demikian penyusunan RPP kurikulum 2013 sudah dilakukan dengan baik sekali dengan ketercapaian kemampuan guru 93\%.

\section{Faktor-faktor yang Mempengaruhi Kemampuan Guru dalam Penyusunan RPP kurikulum} 2013

Dalam proses kegiatan belajar mengajar seorang guru akan mampu melaksankan tugasnya dengan baik apabila memiliki kemampuan dasar atau kompetensi keguruan yang mutlak. Dari hasil penelitian penulis dilapangan mengenai kemampuan guru PAI dalam penyusunan RPP kurikulum 
2013 di SDN 016 Sumber datar Singingi adapun faktor-faktornya sebagai berikut:

1. Faktor Interen

a. Kepribadian, pengetahuan guru tentang penyusunan RPP.

b. Kemampuan guru dalam mengelola kelas.

c. Kurangnya minat guru dalam mengikuti pelatihan pengembangan kemampuan guru.

Hal tersebut akan sangat berpengaruh terhadap kemampuan guru PAI dalam melaksanakan tugasnya sebagai seorang pendidik didalam kegiatan belajar mengajar terutama didalam penyusunan RPP kurikulum 2013 yang merupakan bagian penting dalam pembelajaran.

2. Faktor Eksteren

a. Keterbatasan guru dalam menggunakan media elektronik

b. Kurangnya media pembelajaran yang tersedia disekolah

Hal itu disebabkan kurangnya minat guru dalam menggunakan media elektronik yang berpengaruh terhadap proses penyusunan RPP kurikulum 2013, namun hal tersebut telah diatasi dengan diadakannya pelatihan untuk menunjang kemampuan professional guru.

Seperti yang disampaikan oleh ibu Istiana bahwa salah satu faktor yang mempengaruhi kemampuan guru dalam menyusun RPP adalah keterbatasan pengetahuan guru dalam menysun RPP dan adanya kesulitan dalam menggunakan media elektronik.

Dalam implementasi kurikulum 2013, guru berkewajiban membuat RPP yang berfungsi untuk acuan kegiatan pembelajaran dikelas.RPP tersebut tidak selalu berjalan lancar, terkadang apa yang sudah dibuat dan direncanakan bisa berubah-ubah sehingga tidak berjalan sebagaimana mestinya. Hal ini disebabkan karena kondisi kelas yang memungkinkan perubahan model pembelajarannya, yang berdampak pada perubahan penyusunan RPP.Sebagaimana yang disampaikan bapak Priyanta selaku kepala sekolah bahwa format RPP yang selalu berubah-ubah memang sangat berpengaruh untuk para guru secara tidak langsung, sehingga hal tersebut sangat membebani guru dalam penyusunan RPP.

RPP merupakan upaya untuk memperkirakan tindakan yang akan dilakukan dalam kegiatan pembelajaran. RPP perlu dikembangkan untuk mengkoordinasikan komponen pembelajaran, yakni: Kompetensi Dasar, Materi Standar, Indikator hasil belajar dan penilaian. Oleh karena itu setiap pendidik pada satuan pendidikan berkewajiban menyusun RPP secara lengkap dan sistematis agar pembelajaran berlangsung secara interaktif, inspiratif dan efisien.Dalam hal ini sangat diperlukan usaha guru yang dilakukan untuk meningkatkan kemampuan dalam mengelola RPP kurikulum 2013.Sebagaimana yang disampaikan oleh ibu Rahimi, beliau mengatakan bahwa sudah banyak usaha-usaha yang dilakukan untuk meningkatkan kemampuan guru dalam menyusun RPP, seperti memperbanyak mencari informasi mengenai penyusunan RPP serta mengikuti pelatihan.

Analisa data pada penelitian ini didasarkan pada data hasil observasi yang telah disajikan dalam tabel-tabel penyajian data diatas.

Setelah penulis melakukan 4 kali observasi dengan responden yang menjadi subjek penelitian ini yaitu 2 orang guru PAI SDN 016 Sumber Datar Singingi yang telah dijabarkan dalam penyajian data hasil penelitian diatas, serta membandingkan kemampuan guru PAI dalam menyusun RPP serta penerapannya didalam kegiatan pembelajaran dikelas dengan teori-teori tentang penyusunan RPP tersebut yang menyatakan bahwa kemampuan dalam penyusunan RPP yang baik hendaknya meliputi hal-hal berikut:

1. Guru membuat RPP kurikulum 2013

2. Kesesuaian pemilihan kompetensi dasar dengan topik

3. Kesesuaian perumusan pencapaian tujuan pembelajaran dengan kompetensi inti

4. Kejelasan materi pembelajaran

5. Kesesuaian materi pembelajaran dengan kompetensi dasar

6. Kesesuaian metode dengan tujuan, materi, dan karakteristik peserta didik

7. Kejelasan skenario pembelajara (langkah - langkah kegiatan pembelajaran: pendahuluan, inti, penutup)

8. Kerincian dan kejelasan skenario pembelajaran pada tahap kegiatan mengamati

9. Kerincian dan kejelasan skenario pembelajaran pada tahap menanya

10. Kerincian dan kejelasan

11. skenario pembelajaran pada tahap kegiatan eksplorasi 
12. Kerincian dan kejelasan skenario pembelajaran pada tahap kegiatan asosiasi

13. Kerincian dan kejelasan skenario pembelajaran pada tahap kegiatan komunikasi

14. Kesesuain teknik penilaian dengan kompetensi yang akan dicapai

15. Kelengkapan perangkat penilaian ( soal, kunci, rubric penilaian )

Maka dapat diketahui bahwasannya kemampuan Guru Pendidikan Agama Islam di SDN 016

Sumber Datar Singingi dalam penyusunan RPP Kurikulum 2013 sudah dilakukan dengan sangat baik dengan 4 tahapan observasi oleh penulis yaitu dengan rata-rata skor 86,25\% ketercapaian kemampuan. Hal ini terlihat dari beberapa temuan-temuan berikut:

1. Guru membuat RPP untuk setiap kali tatap muka

2. Dalam mengajar guru menguasai kelas dengan baik

3. Guru mampu mengatasi berbagai karakteristik anak didik

4. Guru menggunakan metode pembelajaran yg sesuai dg materi ajar

5. Dalam mengajar guru menyampaikan materi dengan sangat jelas

\section{KESIMPULAN}

Setelah mengumpulkan, mengolah dan menganalisis data yang diperoleh dari penelitian tentang kemampuan penyusunan RPP kurikulum 2013 oleh guru PAI di SDN 016 Sumber Datar Singingi sebagai hasil penelitian yang telah dijabarkan pada bab-bab sebelumnya, dapat diambil kesimpulan:

1. Kemampuan guru PAI dalam penyusunan RPP kurikulum 2013 di SDN 016 Sumber Datar Singingi sudah menunjukan hasil yang baik sekali yang mana didalam proses pembelajaran guru telah membuat dan menyusun RPP kurikulum 2013 secara baik dan benar sesuai acuan dan kebutuhan peserta didik, menggunakan metode yang sesuai dengan materi ajar untuk mencapai tujuan pembelajaran.

2. Faktor - faktor yang mempengaruhi kemampuan Guru PAI dalam penyusunan RPP Kurikulum 2013 adalah:

a. Faktor interen

1) Kepribadian, pengetahuan guru tentang penyusunan RPP.

2) Kemampuan guru dalam mengelola kelas.

3) Kurangnya minat guru dalam mengikuti pelatihan pengembangan kemampuan guru.

b. Faktor eksteren

1) Keterbatasan guru dalam menggunakan media elektronik

2) Kurangnya media pembelajaran yang tersedia disekolah

Dalam hal ini kedua faktor tersebut telah diatasi dengan mengadakan pelatihan peningkatan kemampuan guru terutama dalam penyusunan RPP kurikulum 2013, melakukan pembinaan berkelanjutan pada guru dalam menyusun perangkat pembelajaran.

\section{DAFTAR PUSTAKA}

Abdul Majid. 2005. Perencanaan Pembelajaran Mengembangkan Standar Kompetensi Guru. Bandung: PT Remaja Rosdakarya.

Antonius. (2016). Buku Pedoman Guru, Bandung: Yrama Widiya

Bariyah, Lailatul. (2014). Analisis Kesesuaian RPP dan Pelaksanaan Pembelajaran Guru SMPN di Kabupaten Mojokerto pada Sub Materi Fotosintesis dengan Kurikulum 2013. 3(2). 453-460. https://jurnalmahasiswa.unesa.ac.id/index.php/bioedu/article/download/ 9558/9439.

Depdiknas. (2003). UU RI No. 20 Tahun 2003 tentang Sistem Pendidikan Nasional.Jakarta: Depdiknas

Jingga GM. 2013. Panduan Lengkap Menyusun Silabus dan Rencana Pelaksanaan Pembelajaran. Yogyakarta: Araska.

Made Pidarta. 1992. Cara Belajar Mengajar Di Universitas Negara Maju. Jakarta: Bumi Aksara. 
Mizan, A., \& Badrun, K. (2014). Evaluasi Implementasi Kurikulum 2013 pada Pembelajaran Matematika SMP Negeri Kelas VII di Kabupaten Sleman. 2(1). 50-59. https://journal.student.uny.ac.id/ojs/ojs/index.php/jep/article/download/73/65.

Mulyasa E., 2007. Kurikulum Tingkat Satuan Pendidikan. Bandung. PT Remaja :Rosdakarya.

M. Fadillah. 2014. Implementasi Kurikulum 2013 Dalam Pembelajaran SD/MI, SMP/MTs, SMA/MA, Yogyakarta: Ar-Ruzz Media.

Mukhtar. 2013. Metode Praktis Penelitian Deskriptif Kualitatif. Jakarta.

Suharsimi Ari Kunto, 2010. Prosedur Penelitian: SuatuPendekatan Praktek, Jakarta: Rineka Cipta.

Sumanto, 2014. Teori dan Aplikasi Metode Penelitian,Yogyakarta: CAPS.

Yahya, Murip.2013. Profesi Tenaga Kependidikan.Bandung: CV Pustaka Setia

Yuliharti Dkk. 2013. Modul Pengembangan Rencana Pelaksanaan Pembelajaran, Pekanbaru: Zanafa Publishing. 